\title{
PENGARUH SUBSTITUSI TEPUNG UBI JALAR UNGU TERHADAP KUALITAS ROTI TAWAR
}

\author{
Rahmi Holinesti \\ Prodi Tata Boga Jurusan Ilmu Kesejahteraan Keluarga \\ Fakultas Pariwisata dan Perhotelan Universitas Negeri Padang \\ Email: r.holinesti@gmail.com
}

\begin{abstract}
ABSTRAK
Tepung ubi jalar ungu sebagai bahan pangan belum optimal digunakan pada penganekaragaman pengolahan makanan, sedangkan tepung ubi jalar ungu dapat menjadi salah satu alternatif untuk mengganti sebagian dari tepung terigu sebagai bahan utama dari roti tawar. Penelitian ini bertujuan untuk menganalisis pengaruh substitusi tepung ubi jalar ungu sebanyak 5\%, 10\% dan 15\% dari tepung terigu yang digunakan terhadap kualitas eksternal dan kualitas internal, serta tingkat kesukaan dari roti tawar tersebut. Jenis penelitian ini adalah eksperimen murni, menggunakan metode rancangan acak lengkap, yang terdiri dari tiga kali ulangan, serta melibatkan 30 orang panelis. Hasil penelitian menunjukkan bahwa substitusi tepung ubi jalar ungu berpengaruh pada kualitas eksternal (volume, bentuk persegi empat dan bentuk rapi) dan kualitas internal (tekstur lembut dan tekstur halus) yaitu pada umumnya nilai terbaik terdapat pada perlakuan 5\% (X1) serta berpengaruh pada kualitas internal (warna pori-pori, aroma ubi jalar ungu dan rasa ubi jalar ungu) yaitu pada umumnya nilai terbaik terdapat pada perlakuan 15\% (X3), tetapi tidak berpengaruh pada kualitas ekternal (warna kulit) dan kualitas internal (aroma ragi). Pada uji hedonik (kesukaan) panelis lebih menyukai substitusi 5\% (X1) dari pada perlakuan lainnya.

Kata kunci: substitusi, tepung ubi jalar ungu, roti tawar, kualitas, hedonik.
\end{abstract}

\section{PENDAHULUAN}

Keanekaragaman makanan yang terdapat di Indonesia banyak sekali mulai dari makanan asli Indonesia sampai makanan yang dipengaruhi oleh negara asing. Menurut Baidar (2009 : 2) "Makanan bukan saja terdiri dari makanan pokok dan bermacam-macam lauk-pauk dan buah-buahan, tetapi disertai pula dengan bermacam-macam jajanan atau kue-kue". Kue-kue modern yang terdapat di Indonesia saat ini resepnya kebanyakan menggunakan bahan baku tepung terigu. Penggunaan tepung terigu sebagai bahan baku pangan cenderung meningkat tiap tahunnya pada produk patiseri.Untuk mengurangi ketergantungan terhadap tepung terigu, perlu dicari bahan pengganti tepung dari bahan lokal seperti yang berasal dari umbi-umbian.

Salah satu dari umbi-umbian tersebut adalah ubi jalar ungu.Menurut Sarwono dalam Tri (2011 : 1) "Kelemahan ubi jalar ungu adalah cepat busuk jika dalam keadaan segar, karena hanya memiliki masa simpan selama 5 bulan". Oleh karena itu, untuk meningkatkan umur simpan dan nilai ekonomi dari ubi jalar ungu tersebut maka perlu diolah menjadi tepung. Menurut Zuraida dalam Hardoko, dkk (2010 : 25) "Tepung ubi jalar ungu mempunyai kadar abu dan kadar serat yang lebih tinggi, serta kandungan karbohidrat dan kalori yang hampir setara dengan tepung terigu". Hal ini mendukung pemanfaatan tepung ubi jalar sebagai alternatif sumber karbohidrat yang dapat disubstitusikan pada produk terigu dan turunannya yang bernilai tambah bagi kesehatan. Roti tawar merupakan salah satu produk turunan dari terigu yang banyak dikonsumsi oleh masyarakat Indonesia khususnya masyarakat perkotaan.

Salah satu tepung yang mungkin bisa disubstitusikan pada pengolahan roti tawar yaitu tepung ubi jalar ungu. Selain untuk penganekaragaman, pengolahan tepung ubi jalar ungu akan memberikan warna khas ungu pada roti tawar tersebut dan mempengaruhi kualitas rasa yang berbeda dari roti tawar biasa serta juga akan menambah nilai gizi pada roti tawar.

Penelitian ini bertujuan untuk menganalisis pengaruh substitusi tepung ubi jalar ungu sebanyak $5 \%, 10 \%$ dan $15 \%$ dari jumlah tepung terigu yang digunakan terhadap kualitas eksternal (volume, warna kulit, bentuk persegi empat dan bentuk rapi) dan kualitas internal (tekstur lembut, tekstur halus, warna pori-pori, aroma ubi jalar ungu, aroma ragi dan rasa ubi jalar ungu) serta hedonik (kesukaan) dari roti tawar. 


\section{METODOLOGI PENELITIAN}

\section{A. Jenis Penelitian}

Jenis penelitian yang dilakukan adalah eksperimen murni (true eksperiment), yaitu melakukan percobaan langsung tentang pengaruh substitusi tepung ubi jalar ungu terhadap kualitas roti tawar.

\section{B. Lokasi dan Jadwal Penelitian}

Penelitian ini dilaksanakan pada bulan Juli 2016 di Workshop Tata Boga, Jurusan Ilmu Kesejahteraan Keluarga, Fakultas Pariwisata dan Perhotelan, Universitas Negeri Padang.

\section{Prosedur Penelitian}

\section{a. Tahap Persiapan}

1) Bahan: tepung terigu cakra, tepung ubi jalar ungu, ragi, air, gula pasir, susu bubuk, lemak dan garam.

2) Alat: timbangan, gelas ukur, waskom stainlees steel, piring, ayakan 80 mesh, rolling pin, oven, scraper, proofer dan cetakan roti tawar.

\section{b. Tahap Pengolahan}

Pada penelitian ini, resep standar yang digunakan adalah resep dari Manfred dan Bogasari (2004 : 32). Untuk lebih jelasnya dapat dilihat pada Tabel 1.

Tabel 1. Bahan-bahan Roti Tawar Ubi Jalar Ungu

\begin{tabular}{clcccc}
\hline \multirow{2}{*}{ No } & \multicolumn{1}{c}{ Bahan } & \multirow{2}{*}{ Kontrol } & \multicolumn{3}{c}{ Resep Penelitian } \\
& & & $5 \%$ & $10 \%$ & $15 \%$ \\
\hline 1. & Tepung Terigu Cakra & $1000 \mathrm{gr}$ & $950 \mathrm{gr}$ & $900 \mathrm{gr}$ & $850 \mathrm{gr}$ \\
2. & Tepung Ubi Jalar Ungu & - & $50 \mathrm{gr}$ & $100 \mathrm{gr}$ & $150 \mathrm{gr}$ \\
3. & Fermipan & $15 \mathrm{gr}$ & $15 \mathrm{gr}$ & $15 \mathrm{gr}$ & $15 \mathrm{gr}$ \\
4. & Gula Pasir & $50 \mathrm{gr}$ & $50 \mathrm{gr}$ & $50 \mathrm{gr}$ & $50 \mathrm{gr}$ \\
5. & Susu Bubuk & $20 \mathrm{gr}$ & $20 \mathrm{gr}$ & $20 \mathrm{gr}$ & $20 \mathrm{gr}$ \\
6. & Air & $620 \mathrm{ml}$ & $620 \mathrm{ml}$ & $620 \mathrm{ml}$ & $620 \mathrm{ml}$ \\
7. & Mentega Putih & $40 \mathrm{gr}$ & $40 \mathrm{gr}$ & $40 \mathrm{gr}$ & $40 \mathrm{gr}$ \\
8. & Garam & $15 \mathrm{gr}$ & $15 \mathrm{gr}$ & $15 \mathrm{gr}$ & $15 \mathrm{gr}$ \\
\hline
\end{tabular}

Proses Pembuatan:

a. Campur tepung terigu, tepung ubi jalar ungu, ragi, gula pasir, susu bubuk dan garam aduk sampai rata. Tambahkan air sedikit demi sedikit sampai tercampur rata.

b. Masukkan mentega putih aduk sampai kalis. Bulatkan adonan, diamkan selama 10 menit dalam lemari pengembang. Kempiskan adonan, timbang tiap adonan 800 gram, lalu bulatkan.

c. Diamkan lagi adonan selama 20 menit. Kempiskan adonan dengan rolling pin, lalu gulung adonan dan potong adonan menjadi 2 bagian.

d. Siapkan loyang berukuran $30 \mathrm{~cm} \times 12 \mathrm{~cm} \times 12 \mathrm{~cm}$ yang diberi pembatas di tengahya dan sudah diolesi mentega putih. Letakkan 4 potong adonan ke dalam loyang dengan 2 perlakuan yang berbeda secara melintang, tekan-tekan adonan agar padat. Diamkan adonan selama 1 jam, lalu tutup loyang seluruhnya.

e. Panggang dalam oven yang sudah dipanaskan pada suhu $180^{\circ} \mathrm{C}$ selama 45 menit.

\section{c. Tahap Uji Organoleptik}

Roti tawar yang sudah matang diletakkan pada wadah yang telah diberikan kode sampel dan disajikan di meja panelis serta dilengkapi dengan format uji organoleptik, selanjutnya panelis memberikan penilaian terhadap roti tawar tanpa substitusi tepung ubi jalar ungu dan roti tawar yang disubstitusikan tepung ubi jalar ungu sebanyak 5\%, 10\% dan 15\% terhadap kualitas roti tawar. 


\section{HASIL DAN PEMBAHASAN}

\section{A. Hasil Penelitian}

1. Deskripsi Data Kualitas Eksternal Roti Tawar dengan Substitusi Tepung Ubi Jalar Ungu (0\%, 5\%, $10 \%$ dan 15\%) Pada Uji Jenjang

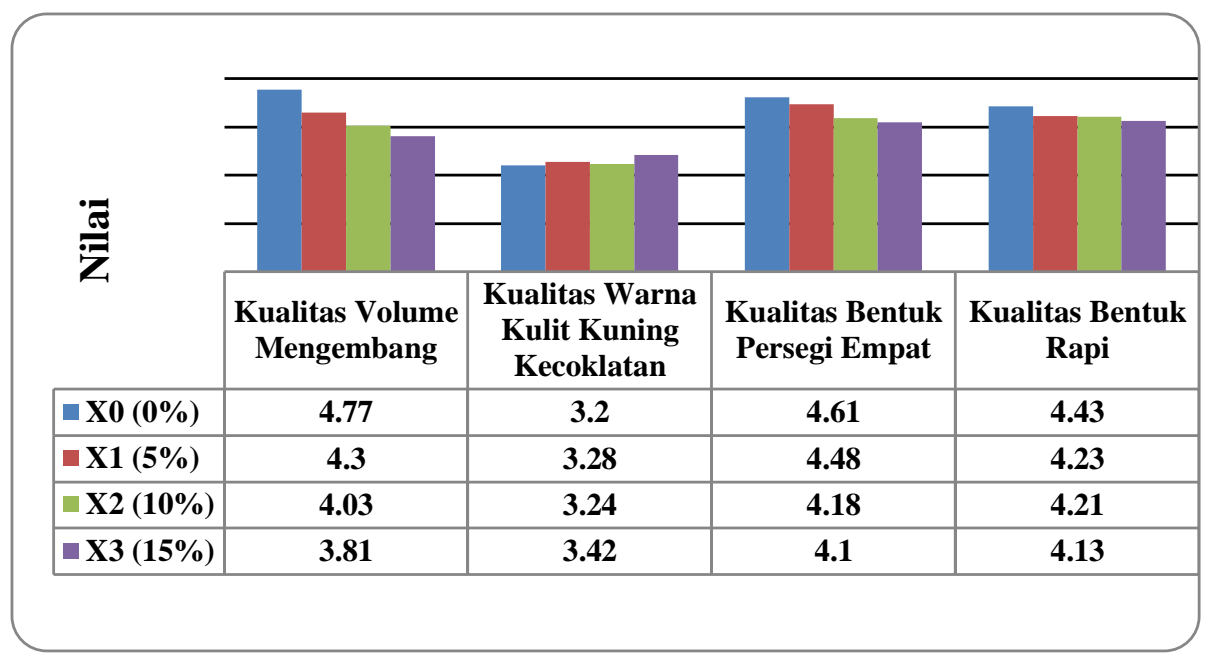

Gambar 2. Rata-rata Skor Kualitas Eksternal Roti Tawar dengan Substitusi Tepung Ubi Jalar Ungu

Berdasarkan Gambar 2 di atas, dapat dijelaskan bahwa nilai rata-rata uji jenjang untuk kualitas eksternal roti tawar pada kualitas volume (mengembang) perlakuan $0 \%\left(\mathrm{X}_{0}\right)$ adalah sangat mengembang dan perlakuan 5\% $\left(\mathrm{X}_{1}\right), 10 \%\left(\mathrm{X}_{2}\right)$ dan 15\% $\left(\mathrm{X}_{3}\right)$ adalah mengembang. Pada kualitas warna kulit (kuning kecoklatan)perlakuan 0\% ( $\left.\mathrm{X}_{0}\right), 5 \%\left(\mathrm{X}_{1}\right), 10 \%\left(\mathrm{X}_{2}\right)$ dan 15\% $\left(\mathrm{X}_{3}\right)$ memiliki warna kulit agak kuning kecoklatan. Pada Kualitas bentuk (persegi empat) perlakuan $0 \%\left(\mathrm{X}_{0}\right)$ dengan bentuk sangat persegi empat dan perlakuan 5\% $\left(\mathrm{X}_{1}\right), 10 \%\left(\mathrm{X}_{2}\right)$ dan $15 \%\left(\mathrm{X}_{3}\right)$ dengan bentuk persegi empat. Pada Kualitas bentuk (rapi) perlakuan $0 \%\left(\mathrm{X}_{0}\right), 5 \%\left(\mathrm{X}_{1}\right), 10 \%\left(\mathrm{X}_{2}\right)$ dan $15 \%\left(\mathrm{X}_{3}\right)$ memiliki bentuk rapi.

\section{Deskripsi Data Kualitas Internal Roti Tawar dengan Substitusi Tepung Ubi Jalar Ungu} $(0 \%, 5 \%, 10 \%$ dan 15\%) Pada Uji Jenjang

Berdasarkan Gambar, dapat dijelaskan bahwa nilai rata-rata uji jenjang untuk kualitas internal roti tawar pada kualitas tekstur (lembut) perlakuan 0\%,5\% dan 10\% memiliki tekstur lembut sedangkan perlakuan 15\% memiliki tekstur agak lembut. Pada kualitas tekstur halus (pori-pori) perlakuan 0\%, 5\% dan 10\% memiliki tekstur halus sedangkan perlakuan $15 \%$ memiliki tekstur agak halus. Pada kualitas warna pori-pori (ungu) perlakuan 0\% memiliki warna sangat tidak bewarna ungu, perlakuan 5\% memiliki warna agak bewarna ungu, perlakuan $10 \%$ memiliki warna ungu dan perlakuan $15 \%$ memiliki warna sangat ungu. Pada kualitas aroma (ubi jalar ungu) perlakuan $0 \%$ sangat tidak beraroma ubi jalar ungu, perlakuan 5\% agak beraroma ubi jalar ungu, perlakuan $10 \%$ dan $15 \%$ beraroma ubi jalar ungu. Pada kualitas aroma (ragi) perlakuan $0 \%, 5 \%, 10 \%$ dan $15 \%$ beraroma ragi. Pada kualitas rasa (ubi jalar ungu) perlakuan $0 \%$ sangat tidak terasa ubi jalar ungu, perlakuan $5 \%$ agak terasa ubi jalar ungu, perlakuan $10 \%$ dan $15 \%$ terasa ubi jalar ungu.

\section{Deskripsi Data Kualitas EksternalRoti Tawar dengan Substitusi Tepung Ubi Jalar Ungu} $(0 \%, 5 \%, 10 \%$ dan $15 \%)$ Pada Uji Hedonik

Berdasarkan Gambar 4, dapat dijelaskan bahwa nilai rata-rata uji hedonik untuk kualitas eksternal roti tawar pada kualitas volume (mengembang) panelis sangat suka pada perlakuan $0 \%\left(\mathrm{X}_{0}\right)$ dan suka pada perlakuan 5\% ( $\left.\mathrm{X}_{1}\right), 10 \%\left(\mathrm{X}_{2}\right)$ dan $15 \%\left(\mathrm{X}_{3}\right)$. Pada kualitas warna kulit (kuning kecoklatan)panelis menyukai perlakuan $0 \%\left(\mathrm{X}_{0}\right), 5 \%\left(\mathrm{X}_{1}\right), 10 \%\left(\mathrm{X}_{2}\right)$ dan $15 \%\left(\mathrm{X}_{3}\right)$. Pada Kualitas bentuk (persegi empat) panelis menyukai perlakuan $0 \%\left(\mathrm{X}_{0}\right), 5 \%\left(\mathrm{X}_{1}\right), 10 \%\left(\mathrm{X}_{2}\right)$ dan $15 \%\left(\mathrm{X}_{3}\right)$. Pada Kualitas bentuk (rapi) panelis menyukai perlakuan $0 \%\left(\mathrm{X}_{0}\right), 5 \%\left(\mathrm{X}_{1}\right), 10 \%\left(\mathrm{X}_{2}\right)$ dan $15 \%\left(\mathrm{X}_{3}\right)$. 


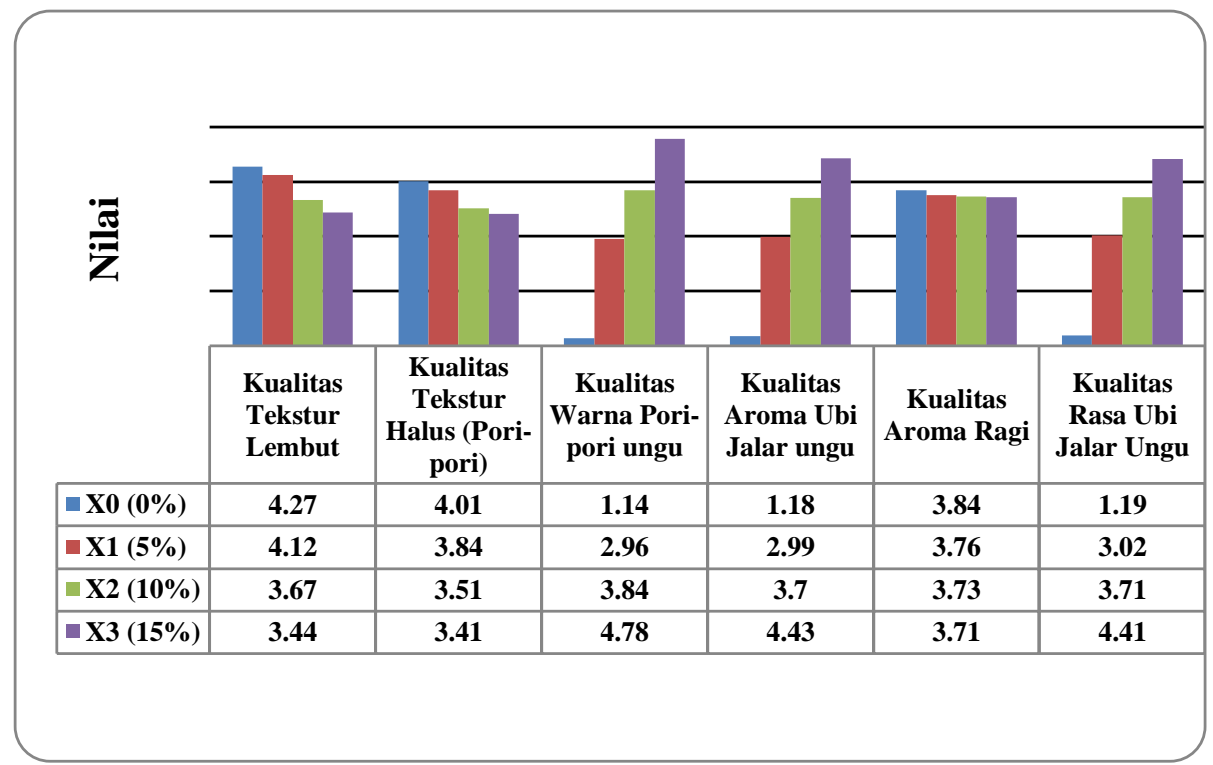

Gambar 3.Rata-rata Skor Kualitas Internal Roti Tawar dengan Substitusi Tepung Ubi Jalar Ungu

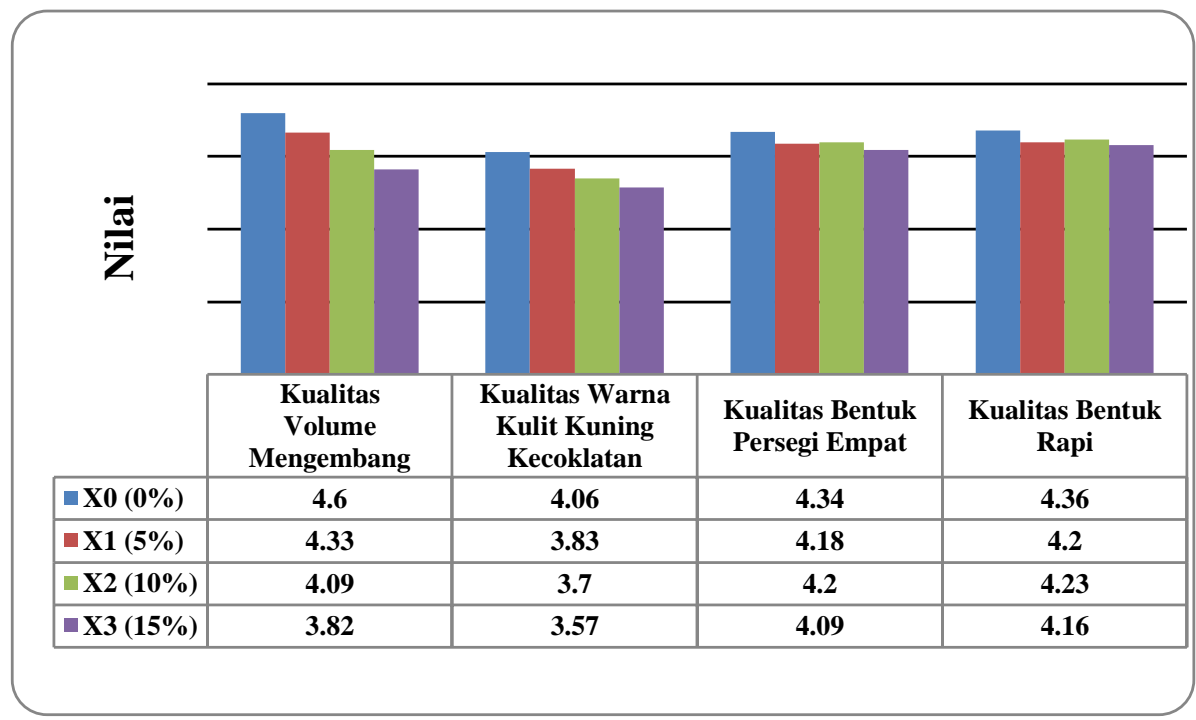

Gambar 4.Rata-rata Skor Hedonik Kualitas Eksternal Roti Tawar dengan Substitusi Tepung Ubi Jalar Ungu

\section{Deskripsi Data Kualitas Internal Roti Tawar dengan Substitusi Tepung Ubi Jalar Ungu (0\%, 5\%, 10\% dan 15\%) Pada Uji Hedonik}

Berdasarkan Gambar 5, dapat dijelaskan bahwa nilai rata-rata uji hedonik untuk kualitas internal roti tawar pada kualitas tekstur (lembut) panelis menyukai perlakuan $0 \%\left(\mathrm{X}_{0}\right), 5 \%\left(\mathrm{X}_{1}\right), 10 \%$ $\left(\mathrm{X}_{2}\right)$ dan $15 \%\left(\mathrm{X}_{3}\right)$. Pada kualitas tekstur halus (pori-pori) panelis menyukai perlakuan $0 \%\left(\mathrm{X}_{0}\right), 5 \%$ $\left(\mathrm{X}_{1}\right), 10 \%\left(\mathrm{X}_{2}\right)$ dan $15 \%\left(\mathrm{X}_{3}\right)$. Pada kualitas warna pori-pori (ungu) panelis menyukai perlakuan $0 \%$ $\left(\mathrm{X}_{0}\right), 5 \%\left(\mathrm{X}_{1}\right), 10 \%\left(\mathrm{X}_{2}\right)$ dan $15 \%\left(\mathrm{X}_{3}\right)$. Pada kualitas aroma (ubi jalar ungu) panelis agak suka pada perlakuan $0 \%$ dan suka pada perlakuan $5 \%\left(\mathrm{X}_{1}\right), 10 \%\left(\mathrm{X}_{2}\right)$ dan $15 \%\left(\mathrm{X}_{3}\right)$. Pada kualitas aroma (ragi) panelis menyukai perlakuan $0 \%\left(\mathrm{X}_{0}\right), 5 \%\left(\mathrm{X}_{1}\right), 10 \%\left(\mathrm{X}_{2}\right)$ dan $15 \%\left(\mathrm{X}_{3}\right)$. Pada kualitas rasa (ubi jalar ungu) panelis menyukai perlakuan $0 \%\left(\mathrm{X}_{0}\right), 5 \%\left(\mathrm{X}_{1}\right), 10 \%\left(\mathrm{X}_{2}\right)$ dan $15 \%\left(\mathrm{X}_{3}\right)$. 


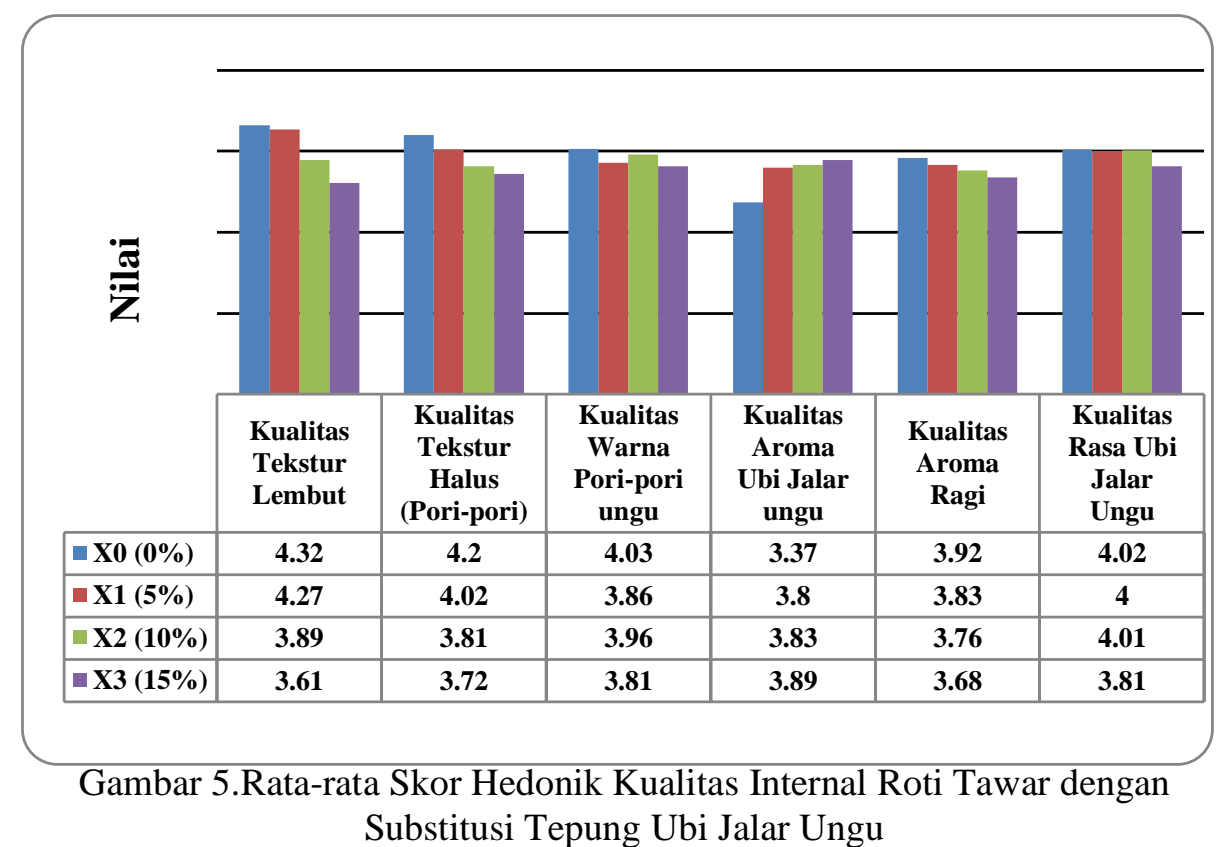

B. Pembahasan

a. Pengaruh Substitusi Tepung Ubi Jalar Ungu Terhadap Kualitas Eksternal Roti Tawar

1) Kualitas Volume (Mengembang) Roti Tawar dengan Substitusi Tepung Ubi Jalar Ungu $(0 \%, 5 \%, 10 \%$ dan $15 \%)$

Hasil analisis ANAVA menyatakan Ha diterima yang artinya terdapat pengaruh yang signifikan terhadap kualitas volume (mengembang) roti tawar dengan substitusi tepung ubi jalar ungu. Volume (mengembang) pada roti tawar disebabkan oleh bahan yang digunakan yaitu ragi, gula dan gluten pada tepung terigu.

Ragi mempunyai peranan penting dalam proses pengembangan roti dengan bantuan gula. Hal ini sesuai dengan pendapat Manfred dan Bogasari (2004 : 16) "Gula dalam pembuatan roti adalah sebagai makanan ragi (di samping nitrogen) yang dianggap sebagai fungsi utamanya". Selanjutnya pendapat dari US Wheat $(1983: 67)$ "Diwaktu peragian gluten dapat mengatur sehingga volume roti dapat berkembang dengan baik. Karbondioksida yang dihasilkan sewaktu peragian yang tepat akan mengembangkan adonan dan roti. Peragian dapat juga menjadikan aroma dan rasa lezat yang baik pada roti”. Pada tingkat kesukaan, hasil penelitian juga menyatakan Ha diterima yang artinya terdapat pengaruh tingkat kesukaan panelis terhadap volume (mengembang) roti tawar dengan substitusi tepung ubi jalar ungu.

2) Kualitas Warna Kulit (Kuning Kecoklatan) Roti Tawar dengan Substitusi TepungUbi Jalar Ungu (0\%, $5 \%, 10 \%$ dan $15 \%)$

Hasil penelitian menyatakan Ha ditolak yang artinya tidak terdapat pengaruh signifikan terhadap warna kulit yang dihasilkan oleh roti tawar dengan substitusi tepung ubi jalar ungu. Warna yang dihasilkan roti tawar yaitu kuning kecoklatan. Munculnya warna tersebut setelah terjadi proses pemanggangan. Warna kulit yang dihasilkan adalah kuning kecoklatan, menurut pendapat Husin (2013 : 101) "Warna kulit (color of crust) adalah warna keseluruhan kulit roti dari hasil proses pemanggangan. Kulit roti yang diharapkan harus memiliki warna coklat keemasan atau golden brown yang rata, serta bebas dari bintik-bintik hitam atau bergaris".Pada tingkat kesukaan, hasil penelitian menyatakan Ha diterima yang artinya terdapat pengaruh tingkat kesukaan panelis terhadap warna kulit roti tawar dengan substitusi tepung ubi jalar ungu.

3) Kualitas Bentuk (Persegi Empat)Roti Tawar dengan Substitusi Tepung Ubi Jalar Ungu $(0 \%, 5 \%, 10 \%$ dan $15 \%)$

Hasil analisis ANAVA menyatakan Ha diterima yang artinya terdapat pengaruh kualitas bentuk (persegi empat) pada roti tawar. Hal ini dikarenakan oleh substitusi tepung ubi jalar ungu dalam jumlah yang berbeda setiap perlakuan. Bentuk roti tawar terjadi karena dibentuk di dalam cetakan, hal ini 
sesuai dengan pendapat U.S Wheat asociates (1983:173) "proses pembentukan sangat penting karena tidak akan ada hasil produksi yang sempurna melalui proofing dan pembakaran jika pembentukannya tidak baik dan tidak tepat".Pada tingkat kesukaan, hasil penelitian juga menyatakan Ha diterima yang artinya terdapat pengaruh tingkat kesukaan panelis terhadap bentuk (persegi empat) roti tawar dengan substitusi tepung ubi jalar ungu.

4) Kualitas Bentuk (Rapi) Roti Tawar dengan Substitusi TepungUbi Jalar Ungu (0\%, $5 \%$, $10 \%$ dan $15 \%$ )

Hasil analisis ANAVA menyatakan Ha diterima yang artinyaterdapat pengaruh kualitas bentuk (rapi) roti tawar dengan substitusi tepung ubi jalar ungu. Bentuk (rapi) dari roti bisa dilihat dari keserasian bentuk roti, hal ini sesuai dengan pendapat Husin (2013 : 101) "Keserasian bentuk adalah keserasian bentuk antar bagian roti yang dihasilkan tanpa terjadinya penurunan sisi samping roti atau kulit yang terlipat'.Pada tingkat kesukaan, hasil penelitian juga menyatakan Ha diterima yang artinya terdapat pengaruh tingkat kesukaan panelis terhadap bentuk (rapi) roti tawar dengan substitusi tepung ubi jalar ungu.

\section{b. Pengaruh Substitusi Tepung Ubi Jalar Ungu Terhadap Kualitas Internal Roti Tawar}

1) Kualitas Tekstur (Lembut) Roti Tawar dengan Substitusi TepungUbi Jalar Ungu (0\%, $5 \%, 10 \%$ dan $15 \%$ )

Hasil analisis ANAVA menyatakan Ha diterima yang artinya terdapat pengaruh kualitas tekstur (lembut) roti tawar dengan substitusi tepung ubi jalar ungu. Teksturmakanan merupakan komponen yang turut menentukan cita rasa makanan karena sensitivitas indera dipengaruhi oleh konsistensi makanan. Tekstur dari roti tawar ini adalah lembut, hal ini sesuai dengan pendapat U.S Wheat Associates (1983 :122) "tekstur adalah sifat jaringan yang dirasakan kalau kita pegang bagian dalam roti bila roti itu dipotong atau diiris. Jadi sifat jaringan yang diinginkan ialah yang halus betul, lembut dan elastis".Pada tingkat kesukaan, hasil penelitian juga menyatakan Ha diterima yang artinya terdapat pengaruh tingkat kesukaan panelis terhadap tekstur (lembut) roti tawar dengan substitusi tepung ubi jalar ungu.

2) Kualitas Tekstur Halus (Pori-pori) Roti Tawar dengan Substitusi TepungUbi Jalar Ungu $(0 \%, 5 \%, 10 \%$ dan $15 \%)$

Hasil analisis ANAVA menyatakan Ha diterima yang artinyaterdapat pengaruh kualitas tekstur halus (pori-pori) roti tawar dengan substitusi tepung ubi jalar ungu. Tekstur dari roti tawar ini adalah halus (pori-pori) karena pengaruh dari lemak yang dipakai. Lemakmerupakan bahan pengempuk dan membantu proses pengembangan susunan fisik roti yang dipanggang, menurut Husin (2013 : 103) "Tekstur roti yang ideal harus memiliki tekstur yang halus, kemampuan kembali pada kondisi semula saat ditekan dan tidak mudah menggumpal".Pada tingkat kesukaan, hasil penelitian juga menyatakan Ha diterima yang artinya terdapat pengaruh tingkat kesukaan panelis terhadap tekstur halus (pori-pori) roti tawar dengan substitusi tepung ubi jalar ungu.

3) Kualitas Warna Pori-pori(Ungu) Roti Tawar dengan Substitusi TepungUbi Jalar Ungu $(0 \%, 5 \%, 10 \%$ dan $15 \%)$

Hasil analisis ANAVA menyatakan Ha diterima yang artinya terdapat pengaruh kualitas warna pori-pori terhadap roti tawar. Hal ini dikarenakan oleh pensubstitusian tepung ubi jalar ungu dalam jumlah yang berbeda setiap perlakuan. Ubi jalar ungu mempunyai warna ungu yang cukup pekat dan menarik perhatian hal ini sesuai dengan pendapat Wahyu, dkk (2014: 122) "Ubi jalar ungu memiliki warna ungu yang cukup pekat dan menarik perhatian. Warna ungu pada ubi jalar disebabkan oleh adanya pigmen ungu antosianin yang menyebar dari bagian kulit sampai pada daging ubinya".Pada tingkat kesukaan, hasil penelitian menyatakan Ha ditolak yang artinya tidak terdapat pengaruh tingkat kesukaan panelis terhadap warna pori-pori roti tawar dengan substitusi tepung ubi jalar ungu.

4) Kualitas Aroma (Ubi Jalar Ungu) Roti Tawar dengan Substitusi Tepung Ubi Jalar Ungu $(0 \%, 5 \%, 10 \%$ dan $15 \%)$

Hasil analisis ANAVA menyatakan Ha diterima yang artinya terdapat pengaruh kualitas aroma (ubi jalar ungu) roti tawar dengan substitusi tepung ubi jalar. Roti tawar yang disubstitusi dengan tepung ubi jalar ungu ini akan menghasilkan aroma yang berbeda dari roti tawar biasanya. Menurut Pendapat Sjahmien (1992 : 99) "Timbulnya aroma makanan disebabkan oleh terbentuknya senyawa yang mudah 
menguap. Aroma yang dikeluarkan setiap makanan berbeda-beda. Selain itu, cara memasak yang berbeda akan menimbulkan aroma yang berbeda pula".Pada tingkat kesukaan, hasil penelitian juga menyatakan Ha diterima yang artinya terdapat pengaruh tingkat kesukaan panelis terhadap aroma ubi jalar ungu roti tawar dengan substitusi tepung ubi jalar ungu.

5) Kualitas Aroma (Ragi) Roti Tawar dengan Substitusi Tepung Ubi Jalar Ungu (0\%, 5\%, $10 \%$ dan $15 \%$ )

Hasil analisis ANAVA menyatakan Ha ditolak yang artinya tidak terdapat pengaruh kualitas aroma (ragi) roti tawar dengan substitusi tepung ubi jalar ungu. Aroma yang ditimbulkan oleh makanan berpengaruh dalam menentukan kelezatan makanan. Aroma dari roti tawar ini adalah beraroma ragi, hal ini sesuai dengan pendapat U.S Wheat Associates (1983:122) “....aroma dapat dibedakan sebagai berasa gandum, manis, apek, tengik, bercendawan,asam atau polos. Roti yang baik beraroma harum gandum dan ragi".Pada tingkat kesukaan, hasil penelitian menyatakan Ha diterima yang artinya terdapat pengaruh tingkat kesukaan panelis terhadap aroma (ragi) roti tawar dengan substitusi tepung ubi jalar ungu.

6) Kualitas Rasa (Ubi Jalar Ungu) Roti Tawar dengan Substitusi TepungUbi Jalar Ungu $(0 \%, 5 \%, 10 \%$ dan $15 \%)$

Hasil analisis ANAVA menyatakan Ha diterima yang artinyaterdapat pengaruh kualitas rasa (ubi jalar ungu) roti tawar dengan substitusi tepung ubi jalar ungu. Rasa dari roti tawar ini adalah rasa ubi jalar ungu. Menurut Sjahmien (1992:98) bahwa "Rasa merupakan faktor kedua yang menentukan cita rasa makanan setelah penampilan makanan itu sendiri”.Pada tingkat kesukaan, hasil penelitianmenyatakan $\mathrm{Ha}$ ditolak yang artinya tidak terdapat pengaruh tingkat kesukaan panelis terhadap rasa (ubi jalar ungu) roti tawar dengan substitusi tepung ubi jalar ungu.

\section{KESIMPULAN DAN SARAN}

\section{Kesimpulan}

Hasil uji statistik membuktikan bahwa $\mathrm{H}_{\mathrm{a}}$ diterima yang artinya terdapat pengaruh yang nyata pada substitusi tepung ubi jalar ungu terhadap beberapa kualitas eksternal roti tawar yaitu volume (mengembang), bentuk (persegi empat), bentuk (rapi) dan kualitas internal yaitu tekstur (lembut), tekstur (halus), warna pori-pori (ungu), aroma (ubi jalar ungu) dan rasa (ubi jalar ungu), serta $\mathrm{H}_{\mathrm{a}}$ ditolak yang artinya tidak terdapat pengaruh yang nyata pada substitusi tepung ubi jalar ungu terhadap kualitas eksternal roti tawar yaitu warna kulit (kuning kecoklatan) dan kualitas internal yaitu aroma (ragi).

\section{Saran}

Setelah melakukan penenelitian ini peneliti dapat memberikan sumbangan saran bagi pihakpihak terkait dalam bidang Tata Boga, yaitu:

a. Berdasarkan hasil penelitian yang telah dilakukan, sebaiknya menggunakan tepung ubi jalar ungu sebanyak 5\% dalam pembuatan roti tawar, karena apabila lebih akan menurunkan mutu roti tawar seperti tekstur lembut, tekstur halus dan kesukaan terhadap warna ungu roti tawar.

b. Mengingat tingginya kandungan pigmen antosianin (zat warna) yang dapat memberikan warna alami pada ubi jalar ungu, vitamin-vitamin dan mineral, maka disarankan untuk melakukan penelitian tepung ubi jalar ungu pada variabel lain seperti donat, muffin dan lain-lain.

c. Pada saat pemanggangan roti tawar, agar tidak menggunakan panas yang tinggi karena warna dari roti tawar ubi jalar ungu tersebut akan pudar disebabkan karena warna alami tidak tahan panas yang tinggi di atas $150^{\circ} \mathrm{C}$.

\section{DAFTAR PUSTAKA}

Baidar. 2009. Makanan Indonesia. Padang : Program Pascasarjana Universitas Negeri Padang.

Dwi Setyaningsih, Anton Apriyantono dan Maya Puspita Sari. 2010. AnalisisSensoriUntukIndustriPangandan Agro.Bogor : IPB Pres. 
Hardoko, Liana Hendarto dan Tagor Marsillam Siregar. 2010. Pemanfaatan Ubi Jalar Ungu (Ipomea Batatas L. Poir) Sebagai Pengganti Sebagian Tepung Terigu dan Sumber Antioksidan Pada Roti Tawar. Jurnal Teknologi dan Industri Pangan, Vol. XXI. No. 1. Hlm 25 - 32.

Husin Syarbini. 2013. A-Z Bakery. Solo : PT Tiga Serangkai Pustaka Mandiri.

Lange, Manfred \& Bogasari Baking Centre. 2004. Roti :Teori dan Resep Internasional. Jakarta : PT Gaya Favorit Press.

Sjahmien Moehyi. 1992. Penyelenggara Makanan Institusi dan Jasa Boga. Jakarta : Bhratara

Tri Marta Fadhilah. 2011. Studi Eksperimen Pembuatan Roti Tawar Dengan Substitusi Ubi Jalar Ungu (Ipomea Batatas). Surakarta : Program Pasca Sarjana Universitas Negeri Sebelas Maret.

U.S. Wheat Associate. 1983. Pedoman Pembuatan Kue dan Roti. Jakarta : Djambatan.

Wahyu EkaArief Santoso dan Teti Estiasih. 2014. Kopigmentasi Ubi Jalar Ungu (Ipomoea batatas var.Ayamurasaki) Dengan Kopigmen Na-Kaseinatdan Protein Whey Serta Stabilitasnya Terhadap Pemanasan. Jurnal Pangan dan Agroindustri, Vol. 2. No. 4. Hlm 121 - 127. 